\title{
Keterbacaan Teks-Teks pada Buku Bahasa Indonesia Kelas VII Kurikulum 2013 Revisi 2017 (Analisis Fry)
}

Journal of Language learning

and Research (JOLLAR)

2019, Vol. 3(2)55-64

(C) Author, 2019

DOI: 10.22236/JOLLAR_3(2)55-64

\section{Muhammad Yusuf Saputro ${ }^{5}$ Universitas Muhammadiyah Prof. DR. HAMKA}

\begin{abstract}
Abstrak
Penelitian ini bertujuan untuk memperoleh gambaran tentang tingkat keterbacaan teks-teks yang ada pada buku siswa kelas VII kurikulum 2013 revisi 2017 yang diterbitkan oleh Kementerian Pendidikan dan Kebudayaan Republik Indonesia. Pendekatan kualitatif dengan metode analisis isi yang digunakan dalam penelitian ini. Pemilihan data dalam penelitian ini menggunakan teknik purposive random sampling dari seluruh teks yang ada pada buku tersebut. Hasil penelitian dari 8 jenis teks dipilih sampel 6 jenis teks. Teks yang sesuai dengan kriteria keterbacaan jenjang kelas VII berjumlah 5 teks, dan 1 teks tidak sesuai kriteria. Penelitian ini penting dilakukan karena kualitas teks dalam buku menentukan tujuan dibuatnya buku tersebut terlebih tujuan dari pembelajaran tersebut. Teks yang tidak memenuhi kriteria dan dipakai secara nasional akan berdampak sangat besar bagi pemahaman peserta didik yang ada di Indonesia. Dengan demikian, perlu adanya penelitian yang mendalam untuk melihat kesesuaian teks dalam buku teks siswa yang telah direvisi ini agar dapat memberikan dampak positif untuk pembelajaran bahasa Indonesia.
\end{abstract}

Kata Kunci: Keterbacaan, Buku Teks, Grafik Fry

\begin{abstract}
The purpose of this study was to obtain an overview of the text readability that is written in the Seventh Grade Indonesian Textbook curriculum 2013 revised 2017 published by the Ministry of Education and Culture of The Republic of Indonesia. A qualitative approach to the content analysis method used in this study. The data selection in this study used a purposive random sampling technique from all the texts in the book.. According to the results of the study of eight types of text, it was selected six types of text as samples of the study. It was obtained that the texts which fit the study considered to be important because the quality of the texts in the book determines the purpose of composing the book, especially the purpose of the learning which is going to be applied. Texts that do not meet the criteria and are used nationally would have a profound impact on the understanding of learners in Indonesia. Thus, there is a need for in-depth research to see the suitability of the text in the revised student textbook to have a positive impact on Indonesian language learning.
\end{abstract}

Keywords: Readability, Text Book, Fry Graph

\footnotetext{
${ }^{5}$ Correspoonding author: msaputro@uhamka.ac.id
} 


\section{PENDAHULUAN}

Buku teks mata pelajaran bahasa Indonesia kurikulum 2013 dengan revisi tahun 2017 disusun dengan tujuan agar para siswa memiliki kompetensi berbahasa Indonesia untuk berbagai fungsi komunikasi dalam kegiatan interaksi sosial di masyarakat baik secara lisan, maupun tulisan. Selain itu pula, diharapkan mampu menumbuhkan minat membaca dan menulis dalam pengembangan kompetensi berbahasa, kognitif, kepribadian, serta emosional siswa.

Buku teks adalah buku pelajaran dalam bidang studi tertentu, yang merupakan buku standar, yang disusun oleh para pakar dalam bidang tersebut guna maksud dan tujuan interaksional, yang dilengkapi dengan sarana-sarana pengajaran yang serasi dan mudah dipahami oleh para pemakainya di sekolah-sekolah dan perguruan tinggi sehingga menunjang sesuatu program pengajaran (Tarigan, 2009:13). Buku teks biasanya disebut juga sebagai buku paket atau buku pelajaran. Lebih lanjut, Dirjen pendidikan menengah umum (2004:3) menyebutkan bahwa buku teks (pelajaran) adalah kumpulan tulisan yang disusun dengan sistematis yang berisi materi-materi pelajaran tertentu, yang disiapkan oleh penulisnya dengan menggunakan acuan kurikulum yang berlaku. Komponen isi yang ada dalam buku teks diturunkan dari kompetensi yang harus dikuasai oleh siswa.

Buku teks yang diterbitkan oleh Kementerian Pendidikan dan Kebudayaan Republik Indonesia telah dilakukan revisi beberapa kali pada semua jenjang yang mengikuti peraturan perundang-undangan yang berlaku. Contohnya pada buku siswa kelas VII kurikulum 2013 terbit pertama kali tahun 2013 kemudian seiring perkembangan dunia pendidikan muncul revisi beriringan dengan Undang-Undang Nomor 24 Tahun 2016 tentang Kompetensi Inti dan Kompetensi Dasar Pelajaran pada Kurikulum 2013 pada Pendidikan Dasar dan Pendidikan Menengah, terbitlah buku siswa kelas VII Kurikulum 2013 Revisi 2017 dengan penyesuaian isi kompetensi dasar yang berubah pula.

Proses perevisian buku teks ini tentu melibatkan penulis yang ahli pada bidang pendidikan bahasa dan sastra Indonesia dan ditelaah oleh ahli pada bidangnya pula dengan standardisasi yang sangat ketat agar memenuhi tujuan adanya buku teks tersebut. Kelayakan buku teks haruslah terpenuhinya berbagai standar yang salah satunya adalah keterbacaan. Hal tersebut sesuai dengan komponen penilaian yang telah ditetapkan Badan Standar Nasional Pendidikan (BSNP). Penilaian BSNP ini mencakup isi atau materi, penyajian materi, bahasa, keterbacaan, dan kegrafikan. Walaupun, proses perevisian sudah melalui proses standardisasi yang tinggi, tetapi hasil proses pemilihan teks dalam buku tersebut tidak bersifat terbuka sehingga memerlukan perhatian khusus.

Buku teks perlu diperhatikan dan disajikan dalam bentuk yang tidak hanya menarik secara visual tetapi juga mudah dimengerti yaitu aspek keterbacaan 
(readability) dari sebuah buku bacaan atau teks bacaan. Keterbacaan suatu bacaan atau teks harus sesuai dengan kemampuan membaca pembacanya. (Saroni, Mudiono, \& HS, 2013).

Keterbacaan adalah hal yang membahas tentang tingkat kesulitan dan kemudahan teks atau bacaan bagi pembaca pada jenjang atau tingkatan kelas tertentu (Idhoofiyatul Fatin, 2017). Keterbacaan sangat berhubungan dengan pemahaman pembaca pada konteks ini adalah siswa dalam pemakaian buku teks. Klare (1984:726) menyatakan bahwa bacaan yang memiliki tingkat keterbacaan yang baik akan berpengaruh pada pembacanya yaitu peserta didik dalam meningkatkan minat belajar dan daya ingat, menambah kecepatan dan efisiensi membaca, dan memelihara kebiasaan membacanya. Jika keterbacaan buku teks tersebut terlalu tinggi menyebabkan tidak terbaca sehingga siswa pun tidak dapat memahami teks tersebut. Jika terlalu rendah, maka siswa juga akan merasa gampang dalam pemahaman teks itu. Seharusnya teks yang baik untuk kelas VII adalah teks yang keterbacaannya berada pada jenjang kelas VII. Buku teks kurikulum 2013 yang telah direvisi tahun 2017 ini belum ditemukan penelitian tentang uji keterbacaan karena memang masih tergolong baru dalam pemakaiannya. Dengan demikian pentingnya pengujian keterbacaan teks yang ada pada buku siswa khususnya kelas VII kurikulum 2013 revisi 2017.

Penelitian-penelitian sebelumnya yang telah melakukan analisis keterbacaan dengan objek yang berbeda menunjukkan bahwa keterbacaan suatu teks atau wacana dilihat dari panjang dan pendek kalimat serta tingkat kesulitan kata. Dewasa ini untuk menganalisis keterbacaan suatu teks dapat dilakukan dengan beberapa cara antara lain grafik Fry dan grafik Raygor yang dianggap praktis dalam mengukur keterbacaan suatu teks (Arif, Lubis, \& Barus, 2013). Grafik fry dalam penelitian ini dipilih terbilang sederhana itu, penulis menganggap formula keterbacaan Fry lebih efisien untuk dipergunakan (Gumono, 2016).

Sehubungan dengan hal tersebut, penelitian ini bertujuan untuk memperoleh gambaran tentang tingkat keterbacaan teks-teks yang ada pada buku siswa kelas VII kurikulum 2013 revisi 2017 yang diterbitkan oleh Kementerian Pendidikan dan Kebudayaan Republik Indonesia.

\section{METODOLOGI}

Metode penelitian yang dipilih dalam penelitian ini adalah metode analisis isi dengan pendekatan kualitatif. Penelitian yang dilakukan yaitu mengukur tingkat keterbacaan teks-teks yang terdapat pada buku teks pelajaran Bahasa Indonesia untuk siswa kelas VII SMP. Sumber data yang diambil adalah seluruh teks yang ada pada buku tersebut yaitu terdapat delapan jenis teks. Jenis teks pada buku bahasa Indonesia untuk kelas VII ini yaitu teks deskripsi, cerita fantasi, teks prosedur, teks laporan hasil observasi, teks fabel, puisi rakyat, surat, dan teks 
resensi. Dengan teknik purposive sampling dengan kriteria teks berupa prosa untuk teks sastra dan berupa paragraf untuk teks nonsastra sehingga diperoleh sampling 6 teks yaitu teks deskripsi, cerita fantasi, teks prosedur, teks laporan hasil observasi, teks fabel, dan teks resensi. Masing-masing teks diambil random sampling untuk menjadi data dalam penelitian 1 teks untuk setiap jenis teksnya.

Pada penelitian ini formula pengukuran keterbacaan yang diterapkan adalah Formula keterbacaan Fry. Formula keterbacaan Fry yang sering disebut Grafik Fry merupakan salah satu alat ukur keterbacaan yang diperkenalkan oleh Edward Fry. Tata cara penggunaan Formula Fry itu sendiri menurut Harjasujana (1997:116) antara lain sebagai berikut.

1) Dalam menghitung keterbacaan Formula Fry menggunakan seratus kata sebagai sampel tanpa memperhatikan panjangnya teks yang akan diteliti. Dengan demikian meskipun teks yang akan diteliti mencapai berlembarlembar tetapi sampel yang diambil hanya seratus kata.

2) Hitunglah jumlah kalimat dari seratus buah kata tadi hingga perpuluhan terdekat. Maksudnya, jika kata yang terhitung 100 tidak jatuh di ujung kalimat maka akan dihitung dalam bentuk desimal (perpuluhan). Cara melakukan persepuluh adalah jumlah kata yang terhitung dalam 100 kata sampel dibagi dengan jumlah seluruh kata ada kalimat terakhir.

3) Setelah itu, hitunglah suku kata dari teks sampel 100 kata tadi. Untuk angka dan singkatan setiap kelompok lambang diperhitungkan sebagai satu suku kata. Pengukuran keterbacaan untuk bahasa Indonesia perlu dilakukan penyesuaian dengan mengalikan jumlah suku kata dengan angka 0,6.

4) Perhatikan grafik Fry. Kolom tegak lurus menunjukkan jumlah suku kata perseratus kata dan baris mendatar menunjukkan jumlah kalimat per satu kata. Pertemuan antara baris vertikal dan horizontal menunjukkan tingkatantingkatan kelas pembaca. Jika hasil pertemuan antara garis vertikal dan horizontal berada pada daerah gelap maka hasilnya tidak absah.

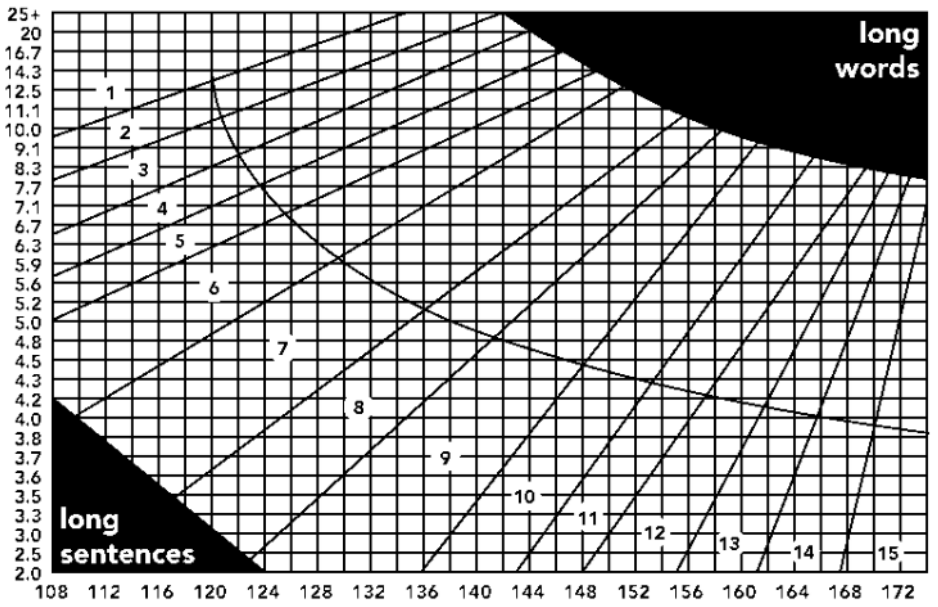


Gambar 1. Grafik Fry

5) Tingkat keterbacaan ini bersifat perkiraan. Penyimpangan mungkin terjadi baik ke atas maupun ke bawah. Oleh karena itu, peringkat keterbacaan hendaklah dikurangi satu atau ditambah satu. Maka dalam penelitian ini tingkat keterbacaan teks terebut harus berada pada tingkat 6,7 , dan 8 .

\section{TEMUAN DAN PEMBAHASAN}

Materi pokok pembelajaran bahasa Indonesia pada kurikulum 2013 sebagian besar berupa teks. Berdasarkan hal tersebut, orientasi pembelajaran bahasa Indonesia adalah teks. Itulah dasar perbedaan kurikulum 2013 dengan kurikulum sebelumnya, yaitu kurikulum 2006 (KTSP). Keterbacaan teks seiring dengan tingkat pemahaman siswa berdasarkan kelas-kelas keterbacaan menjadi alasan yang sangat penting untuk dikaji lebih mendalam dalam penerapan pembelajaran bahasa Indonesia berbasis teks ini. Peran buku dalam pembelajaran bahasa Indonesia yang di dalamnya memuat teks-teks juga akan mengarahkan pada tujuan kurikulum serta tujuan pembelajaran.

Tingkat keterbacaan teks-teks buku pada mata pelajaran bahasa Indonesia dapat diketahui setelah melakukan analisis satu per satu teks dari data yang telah ditentukan. Teks yang dijadikan sampel pada penelitian ini berjudul "Pesona Pantai Senggigi", "Kekuatan Ekor Biru Nataga", "Cara Memainkan Angklung", "Museum", "Kuda Berkulit Harimau", dan "Tenun Biru”. Dari teks-teks tersebut diperoleh hasil sebagai berikut.

\begin{tabular}{llcrc}
\hline No & \multicolumn{1}{c}{ Teks } & $\begin{array}{c}\text { S Suku kata tiap 100 } \\
\text { kata (konversi) }\end{array}$ & $\begin{array}{c}\sum \text { kalimat setiap } \\
100 \text { kata }\end{array}$ & $\begin{array}{c}\text { Kelas } \\
\text { Keterbacaan }\end{array}$ \\
\hline 1 & Teks Deskripsi & 140 suku kata & 10 kalimat & 6 (TS) \\
\hline 2 & Teks Cerita Fantasi & 147 suku kata & 10,1 kalimat & $\mathbf{7}$ (S) \\
\hline 3 & Teks Prosedur & 138 suku kata & 8,2 kalimat & $\mathbf{6}$ (TS) \\
\hline 4 & Teks LHO & 170 suku kata & 7,4 kalimat & $\mathbf{1 2}$ (TS) \\
\hline 5 & Teks Fabel & 136 suku kata & 8 kalimat & $\mathbf{6}$ (TS) \\
\hline 6 & Teks Resensi & 144 suku kata & 6,1 kalimat & $\mathbf{8}$ (TS) \\
\hline & & & Keterangan & TS (Tidak Sesuai) S (Sesuai)
\end{tabular}

Tabel 1. Hasil Analisis Keterbacaan Teks

Dari hasil analisis dari keenam teks sampel penelitian diperoleh tiga teks berkelas keterbacaan 6, yaitu teks deskripsi, teks prosedur, dan teks fabel; satu teks yang berkelas keterbacaan 7 sesuai dengan jenjang kelas sesungguhnya, yaitu teks cerita fantasi; satu teks yang berkelas keterbacaan 8, yaitu teks resensi; dan satu teks yang berkelas keterbacaan 12 , yaitu teks laporan hasil observasi. 


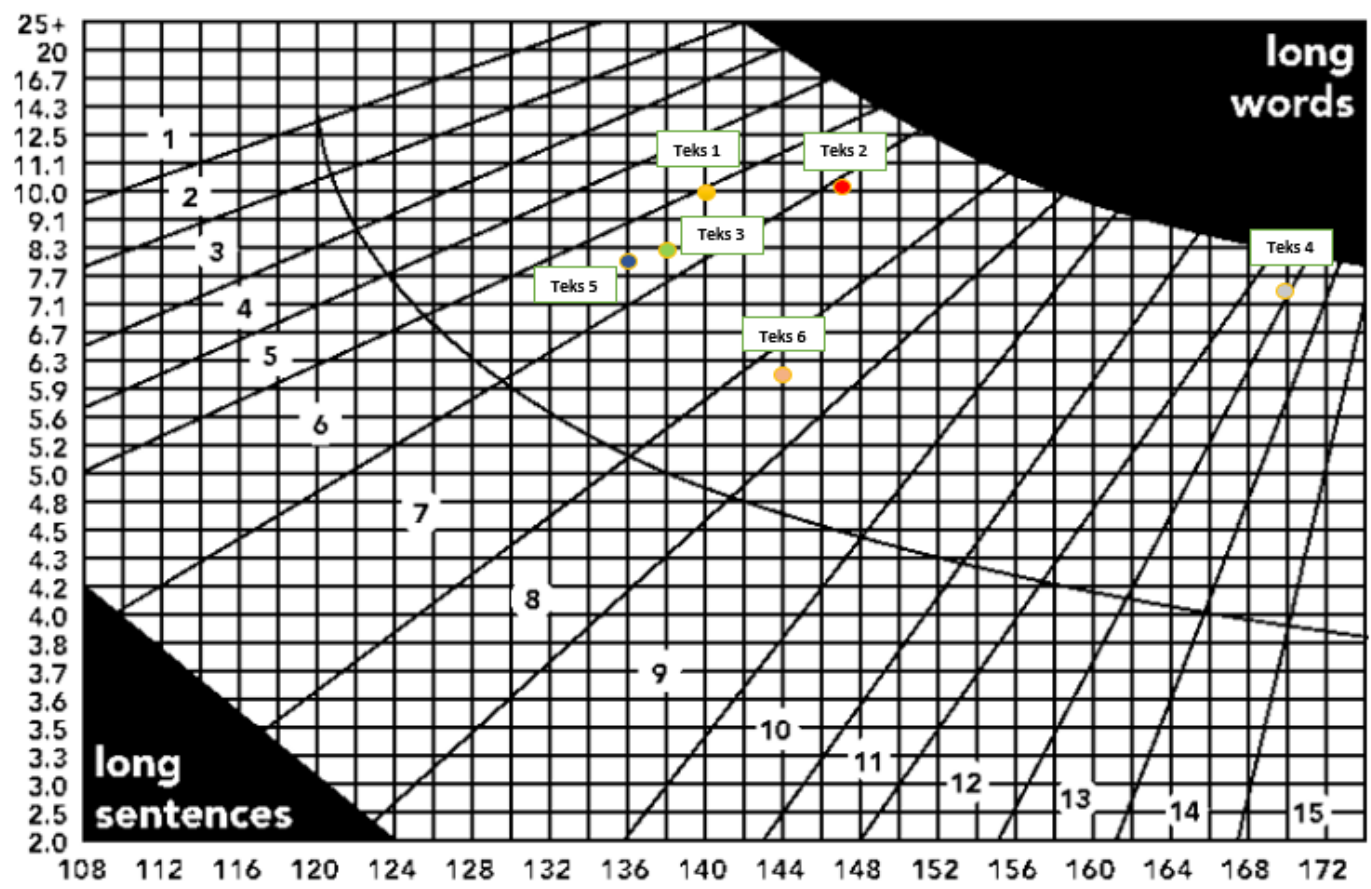

Gambar 2. Persebaran Tingkat Keterbacaan Teks pada Buku Bahasa Indonesia Kelas VII Kurikulum 2013 Revisi 2017

Berikut ini disajikan contoh teks yang berada di kelas keterbacaan 6 yang lebih rendah dari jenjang kelas VII sebenarnya.

Teks 1 Deskripsi (halaman 12-13)

1. Pantai Senggigi merupakan salah satu wisata andalan di Nusa Tenggara Barat.

2. Pantai Senggigi sangat indah. (8 suku kata, 4 kata)

3. Pantai Senggigi terletak di Kecamatan Batu Layar, Kabupaten Lombok Barat, Provinsi Nusa Tenggara Barat. (35 suku kata, 14 kata)

4. Pantai Senggigi merupakan pantai dengan garis pantai terpanjang. (20 suku kata, 8 kata)

5. Pemandangan bawah laut Senggigi juga menakjubkan. (17 suku kata, 6 kata)

6. Pura Bolong menjadi pelengkap wisata di Pantai Senggigi. (19 suku kata, 8 kata)

7. Memasuki bibir Pantai Senggigi kita akan disambut angin pantai yang lembut dan udara yang segar. (32 suku kata, 15 kata)

8. Angin lembut terasa mengelus kulit. (12 suku kata, 5 kata)

9. Garis pantai Senggigi yang panjang dengan gradasi warna pasir putih dan hitam membuat keindahan pantai ini semakin menarik. (41 suku kata, 18 kata) 
10. Ombak yang tenang di pantai ini membuat rasa tenteram semakin lengkap. (23 suku kata, 11 kata)

Teks tersebut memiliki jumlah suku kata 234 suku kata karena teks berbahasa Indonesia maka perlu dikonversikan dengan dikalikan 0,6 sehingga diperoleh 140 suku kata per 100 kata (sudah dikonversi) dan terdiri dari 10 kalimat sehingga masuk dalam kelas keterbacaan 6. Teks tersebut dapat masuk dalam kelas keterbacaan 6 karena struktur kalimat didominasi oleh kalimat tunggal. Pada teks tersebut tersusun dari 8 kalimat tunggal yaitu kalimat ke-1, 2, 3, 4, 5, 6, 8, 10. Selain itu, kata-kata yang digunakan pada teks tersebut cenderung kata yang pendek dan didominasi oleh kata yang tersusun dari satu sampai dua suku kata yang berjumalah 65 kata.

Berikut ini disajikan contoh teks yang berada di kelas keterbacaan 12 yang lebih tinggi dari jenjang kelas VII sebenarnya.

Teks 4 Teks Laporan Hasil Observasi (halaman 126-128)

1. Museum merupakan salah satu tempat penting dalam upaya pelestarian sejarah. (28 suku kata, 10 kata)

2. Museum adalah lembaga yang berfungsi mengumpulkan, merawat, dan menyajikan serta melestarikan warisan budaya masyarakat untuk tujuan studi, penelitian, dan kesenangan atau hiburan. (64 suku kata, 22 kata)

3. Fungsi museum yang utama adalah menyimpan, merawat, mengamankan, dan memanfaatkan koleksi museum berupa benda cagar budaya. (44 suku kata, 16 kata)

4. Dengan demikian, museum memiliki fungsi besar yaitu sebagai tempat pelestarian. (30 suku kata, 10 kata)

5. Secara lebih rinci fungsi museum mencakup kegiatan penyimpanan, perawatan, dan pengamanan. (32 suku kata, 11 kata)

6. Museum dibedakan berdasarkan koleksi dan kedudukannya. (20 suku kata, 6 kata)

7. Jenis museum berdasarkan koleksi yang dimiliki dibedakan menjadi dua jenis yaitu museum umum dan museum khusus. (42 suku kata, 16 kata)

8. Museum Umum adalah museum yang koleksinya terdiri dari kumpulan bukti // material manusia dan atau lingkungannya yang berkaitan dengan berbagai cabang seni, disiplin ilmu, dan teknologi. (24 suku kata, 9 kata)

Teks tersebut memiliki jumlah kata 284 suku kata dan dikonversi dikalikan 0,6 menjadi 170 suku kata per 100 kata (sudah dikonversi) dan terdiri dari 7,4 kalimat sehingga masuk dalam kelas keterbacaan 12. Jumlah kalimat yang tersusun dari 100 kata pada teks tersebut adalah 7,4 kalimat karena kalimat ke-8 tidak terpakai sepenuhnya. Kata ke-100 pada teks tersebut adalah kata bukti pada kalimat 
ke-8 yang ditandai dengan tanda //. Alasan teks tersebut dapat masuk dalam kelas kelas keterbacaan 12 adalah struktur kalimat didominasi oleh kalimat yang panjang. Selain itu, kata-kata yang digunakan sebagian besar adalah kata dasar dan kata bentukkan yang tersusun dari tiga sampai dengan lima suku kata yang berjumlah 62 kata.

Dari enam teks yang dianalisis hanya ada satu teks yang memenuhi kelas keterbacaan 7 sesuai dengan jenjang kelas sebenarnya, yaitu teks cerita fantasi. Berikut ini disajikan teks yang sesuai dengan jenjang kelas VII.

Teks 2 Cerita Fantasi (halaman 45-47)

1. Seluruh pasukan Nataga sudah siap hari itu. (17 suku kata, 7 kata)

2. Nataga membagi tugas kepada seluruh panglima dan pasukannya di titiktitik yang sudah ditentukan. (34 suku kata, 13 kata)

3. Seluruh binatang di Tana Modo tampak gagah dengan keyakinan di dalam hati, mempertahankan milik mereka. (36 suku kata, 15 kata)

4. Hari itu, sejarah besar Tana modo akan terukir di hati seluruh binatang. (27 suku kata, 12 kata)

5. Mereka akan berjuang hingga titik darah penghabisan untuk membela tanah air tercinta. (30 suku kata, 12 kata)

6. Saat yang ditunggu pun tiba. ( 9 suku kata, 5 kata)

7. Mulai terlihat bayangan serigala-serigala yang hendak keluar dari kabut. (25 suku kata, 10 kata)

8. Jumlah pasukan cukup banyak. (9 suku kaya, 4 kata)

9. Nataga dan seluruh panglima memberi isyarat untuk tidak panik. (22 suku kata, 9 kata)

10. Pasukan siluman serigala mulai menginjak Pulau Tana Modo, susul menyusul bagai air. (30 suku kata, 12 kata)

11. Tubuh // mereka besar-besar dengan sorot mata tajam. (2 suku kata, 1 kata)

Teks tersebut telah memenuhi kriteria keterbacaan untuk jenjang kelas VII karena jumlah suku kata 245 suku kata dikonversikan dengan dikalikan 0,6 sehingga menjadi 147 suku kata dan terdiri dari 10,1 kalimat dibulatkan menjadi 10 kalimat. Kalimat ke-11 tidak dipergunakan seluruhnya karena kata ke-100 pada teks tersebut tepat pada kata tubuh yang ditandai dengan tanda //. Alasan teks tersbut dapat menjadi teks dengan keterbacaan yang sesuai adalah jumlah kalimat dan jumlah suku yang memenuhi kriteria yang didukung oleh penggunaan kalimat yang tepat kombinasi antara kalimat tunggal dengan kalimat yang tidak terlalu panjang dan kata-kata yang digunakan juga sesuai yang tersusun dari satu sampai dengan dua suku kata berjumlah 60 kata dan 40 kata tersusun dari 3 suku kata atau lebih.

Analisis keterbacaan menggunakan grafik fry dapat dibuat rentang dengan ditambah satu dan dikurang satu dari kelas keterbacaan yang terukur. Jadi 
berdasarkan analisis yang telah dilakukan dari keenam teks yang memenuhi kriteria keterbacaan untuk jenjang kelas VII adalah teks yang masuk dalam rentang kelas keterbacaan 6,7 , atau 8 . Teks yang sesuai adalah teks deskripsi, teks cerita fantasi, teks prosedur, teks fabel, dan teks resensi. Sedangkan teks yang tidak memenuhi kriteria rentang kelas keterbacaan adalah teks laporan hasil observasi, yang masih melampaui keterbacaan jenjang kelas VII. Seharusnya teks tersebut digunakan pada jenjang kelas $11,12,13$.

\begin{tabular}{|c|c|c|c|c|}
\hline No & Teks & $\begin{array}{l}\sum \text { Sukukata tiap } 100 \\
\text { kata (konversi) }\end{array}$ & $\begin{array}{c}\sum \text { kalimat setiap } \\
100 \text { kata }\end{array}$ & $\begin{array}{c}\text { Rentang Kelas } \\
\text { Keterbacaan } \\
(+1 \text { dan }-1)\end{array}$ \\
\hline 1 & Teks Deskripsi & 140 suku kata & 10 kalimat & $5,6,7(S)$ \\
\hline 2 & Teks Cerita Fantasi & 147 suku kata & 10,1 kalimat & $6,7,8(S)$ \\
\hline 3 & Teks Prosedur & 138 suku kata & 8,2 kalimat & $5,6,7(S)$ \\
\hline 4 & Teks LHO & 170 suku kata & 7,4 kalimat & $\begin{array}{l}\text { 11, 12, } 13 \\
\text { (TS) }\end{array}$ \\
\hline 5 & Teks Fabel & 136 suku kata & 8 kalimat & $5,6,7(S)$ \\
\hline 6 & Teks Resensi & 144 suku kata & 6,1 kalimat & $7,8,9(S)$ \\
\hline
\end{tabular}

Teks laporan hasil observasi tidak sesuai tingkat keterbacaan dapat diperbaiki dengan cara (1) mengubah kalimat panjang atau kalimat majemuk menjadi kalimat pendek atau tunggal, (2) mengganti kata-kata panjang dengan kata-kata lain yang lebih pendek dan maknanya sepadan dengan kata-kata yang diganti, (3) menggabungkan dua kalimat penjelas yang dapat digabung menjadi satu dengan mengatur penyusunan kata hingga menjadi kalimat baru yang mudah dipahami. Begitu pula sebaliknya apabila tingkat keterbacaan teks lebih mudah, maka cara memperbaiki teks tersebut adalah (1) mengubah kalimat pendek atau tunggal menjadi kalimat panjang atau kalimat majemuk, (2) mengganti kata-kata yang pendek dengan kata-kata yang lebih panjang atau pun sulit tetapi memiliki makna yang sepadan dengan kata-kata yang diganti.

Pembelajaran berbasis teks pada kurikulum 2013 ini menekankan pada kualitas teks yang memadai sebagai alat untuk mencapai tujuan pembelajaran dan tujuan buku teks itu sendiri. Oleh sebab itu, maka diperlukan teks-teks yang berkualitas agar peserta didik dapat memahami isi dari teks tersebut terlebih dapat meningkatkan keterampilan berbahasa dengan memfungsikan teks sebagai media komunikasi. 


\section{PENUTUP}

Penelitian keterbacaan teks-teks pada buku teks bahasa Indonesia untuk kelas VII kurikulum 2013 revisi 2017 terbitan Kementerian Pendidikan dan Kebudayaan Republik Indonesia, menggunakan Buku yang dijadikan pokok atau sumber belajar utama ini setelah diuji diperoleh hasil 5 teks memenuhi kriteria keterbacaan jenjang kelas VII yaitu teks teks deskripsi, teks cerita fantasi, teks prosedur, teks fabel, dan teks resensi. Sedangkan 1 teks tidak memenuhi kriteria keterbacaan jenjang kelas VII, yaitu teks laporan hasil observasi. Teks yang tidak sesuai baiknya dilakukan revisi untuk pengembangan buku teks pada pengembangan kurikulum pada tahun mendatang agar fungsi teks tersebut dapat bermanfaat. Karena buku teks siswa ini sudah dipergunakan secara masal, guru mata pelajaran bahasa Indonesia dapat mengganti teks yang tidak sesuai keterbacaannya tersebut dengan teks lain yang sejenis agar peserta didik tidak kesulitan dalam memahami teks tersebut.

\section{DAFTAR PUSTAKA}

Arif, S., Lubis, F., \& Barus, F. L. (2013). Keterbacaan Buku Teks Bahasa Indonesia Kurikulum 2013 Kelas VII dengan Grafik Raygor. Bahas, 27(4), 315-328.

Direktorat Pendidikan Menengah Umum. (2004). Pedoman Umum Pengembangan Bahan Ajar SMA. Jakarta: Direktorat Pendidikan Menengah Umum, Direktorat Jenderal Manajemen Pendidikan Dasar dan Menengah, Departemen Pendidikan Nasional.

Gumono. (2016). Analisis Tingkat Keterbacaan Buku Siswa Bahasa Indonesia Kelas VII Bebasis Kurikulum 2013. Diksa, 2(2), 132-141.

Harjasujana, A.S., Mulyati, Y., (1997). Membaca 2. Jakarta: Departemen Pendidikan dan Kebudayaan.

Harsiati, T., Trianto, A., \& Kosasih, E. (2017). Bahasa Indonesia SMP/MTs Kelas VII Kurikulum 2013 Revisi 2017. Jakarta: Kementertrian Pendidkan dan Kebudayaan Republik Indonesia.

Idhoofiyatul Fatin. (2017). Keterbacaan Buku Teks Bahasa Indonesia Kelas X Kurikulum 2013 Edisi Revisi 2016 dengan Formula Fry. Belajar Bahasa, 2(1), 21-33.

Klare, G.R. (1984). Readability: Handbook of Reading Research. New York: Longman Inc.

Saroni, N., Mudiono, A., \& HS, W. (2013). Analisis Keterbacaan Teks pada Buku Tematik Terpadu Kelas V SD Berdasarkan Grafik Fry. Prosiding Seminar Nasional KSDP Prodi S1 PGSD Universitas Negeri Malang, 157-164.

Tarigan, H.G., Tarigan, Djago., (2009). Telaah Buku Teks Bahasa Indonesia. Bandung: Angkasa. 